\title{
Dinosaur footprints from the Lower Cretaceous of the Algarve Basin (Portugal): New data on the ornithopod palaeoecology and palaeobiogeography of the Iberian Peninsula
}

\author{
Vanda F. Santos ${ }^{\mathrm{a}, \mathrm{b}, *}$, Pedro M. Callapez ${ }^{\mathrm{b}, \mathrm{c}}$, Nuno P.C. Rodrigues ${ }^{\mathrm{a}}$ \\ a Museu Nacional de História Natural e da Ciência, Rua da Escola Politécnica 58, 1250-102 Lisboa, Portugal \\ ${ }^{\mathrm{b}}$ Centro de Geofísica da Universidade de Coimbra (FCT - MCTES), Av. Dr. Dias da Silva, 3000-134 Coimbra, Portugal \\ ${ }^{\mathrm{c}}$ Departamento de Ciências da Terra da Universidade de Coimbra, Lg. Marquês de Pombal, 3001-401 Coimbra, Portugal
}

\section{A R T I C L E I N F O}

\section{Article history:}

Received 30 December 2011

Accepted in revised form 2 July 2012

Available online 3 August 2012

\section{Keywords:}

Dinosaur footprints

Iguanodontia

Iguanodontipus

Lower Cretaceous

Algarve Basin

Portugal

\begin{abstract}
A B S T R A C T
Fieldwork carried out during the past few years in the Algarve region (Portugal) has allowed the description of dinosaur tracks for the first time in the Mesozoic Algarve Basin. Five track levels of Early Barremian age have been described from the Santa and Salema tracksites situated near Vila do Bispo (southwest Algarve). These comprise theropod and iguanodontian footprints (Iguanodontipus isp. was identified at the Santa tracksite). A sequence of subcircular and tridactyl impressions with a characteristic morphology of ornithopod footprints with a high pace angulation value made it possible to determine how erosion changes the print morphology and to understand the sequences of subcircular impressions with a high value of pace angulation in the track record. These dinosaur footprints are preserved in marginal-marine carbonate sediments of a large inner shelf palaeoenvironment with shoals and tidal-flat areas that were periodically exposed. The warm and dry climate favoured extensive growth of algal mats and the deposition of dolomitic sediments. The discovery of these track levels has also enabled the palaeobiogeographical data available for the Early Cretaceous Iguanodontia of the Iberian Peninsula and southwestern Europe to be refined.
\end{abstract}

(c) 2012 Elsevier Ltd. All rights reserved.

\section{Introduction}

The presence of vertebrates in the Mesozoic Algarve Basin (Portugal) was first reported by Palain $(1975,1976)$ followed by Russell and Russell (1977). They mentioned the existence of fish, primitive amphibians and unknown reptiles in at least five levels of the Triassic "Grés de Silves" Formation. Recently, Kasprak et al. (2010) have recognized terrestrial vertebrate material, including remains of large stereospondyl temnospondyls, close to the Triassic/Jurassic boundary. Dinosaur osteological remains were first identified by Pedro Terrinha at Porto de Mós beach (Lagos) in 1992 (Santos et al., 2000a). Here, in an Aptian layer (Clansayesian-Gargasian according to Rey, 1983), dinosaur teeth and longitudinal sections of vertebrae were recognized. An analysis based on visible morphological aspects in section allowed its assignation to theropods (Santos et al., 2000a). Dinosaur tracksites

\footnotetext{
* Corresponding author. Museu Nacional de História Natural e da Ciência, Rua da Escola Politécnica 58, 1250-102 Lisboa, Portugal.

E-mail address: vsantos@museus.ul.pt (V.F. Santos).
}

are still scarce in Mesozoic rocks of the Algarve Basin when compared with the well-documented dinosaur track record from the Mesozoic Lusitanian Basin (Fig. 1), which has been yielding significant palaeobiological and palaeoecological information from abundant tracks and trackways (e.g., Madeira and Dias, 1983; Santos et al., 1992, 1994, 2009a, b; Lockley and Santos, 1993; Lockley et al., 1994b, 1998; Meyer et al., 1994).

Five Cretaceous dinosaur tracksites have been described from the Lusitanian Basin (Fig. 1, Table 1). These contain sauropod, theropod and ornithopod tracks. Among the best evidence of this fossil record are two track levels (Lagosteiros A) in a Berriasian clastic sequence that overlies the Upper Jurassic (Tithonian) limestones in Lagosteiros Bay, north of Cabo Espichel (Sesimbra), which were discovered by José Luís d'Orey in 1996. Here, dinoturbation and bipedal dinosaur tracks of probable theropod origin were identified (Santos, 2003). In the north cliff of Lagosteiros Bay, theropod footprints and a probable ornithopod trackway were documented in a single track level (Lagosteiros B) of Hauterivian age (e.g., Antunes, 1976; Santos et al., 1992; Meyer et al., 1994; Santos, 2003). An Early Aptian tracksite at Praia Grande (Sintra) consists of an upper level with sauropod, theropod and ornithopod 


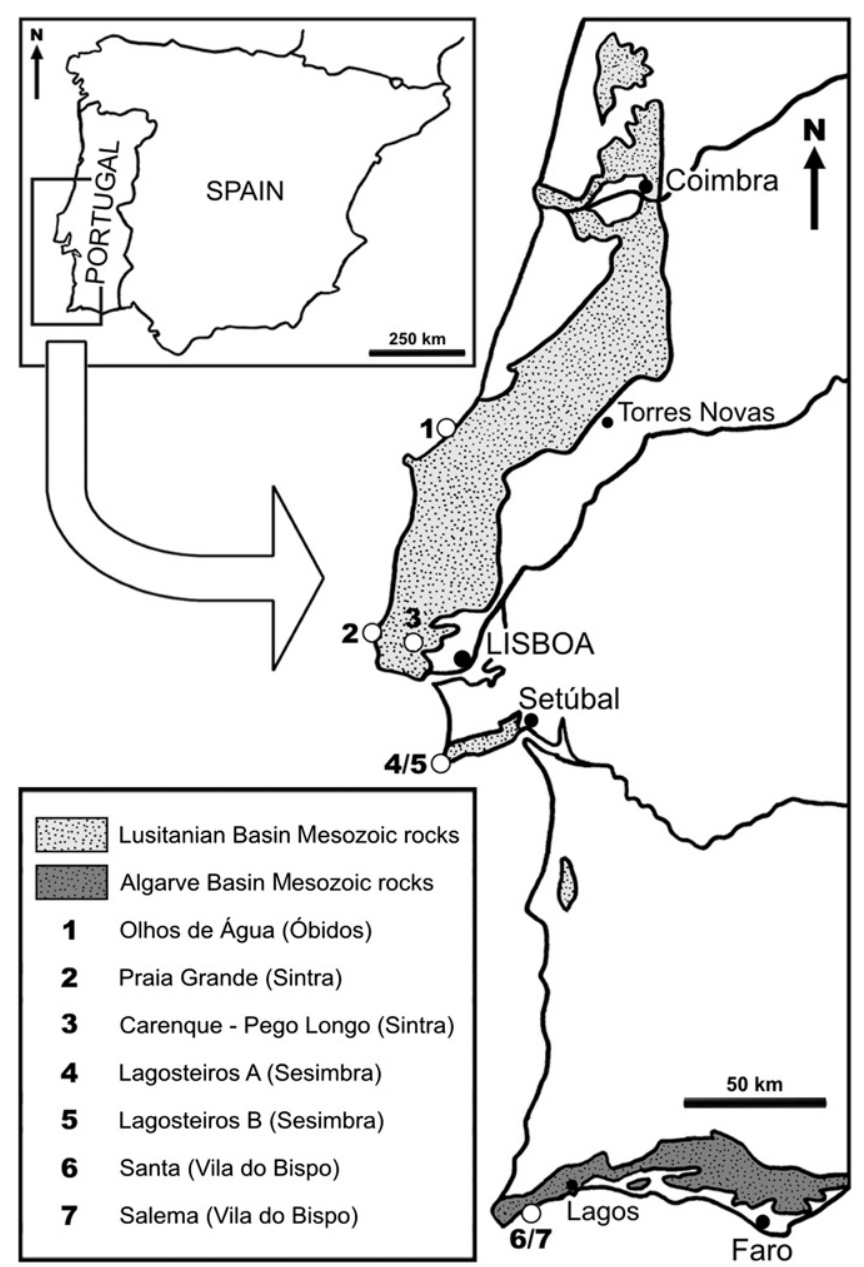

Fig. 1. Cretaceous dinosaur tracksites in the Mesozoic Lusitanian and Algarve basins (Portugal).

tracks, and a lower level with dinoturbation (Madeira and Dias, 1983; Lockley et al., 1994a; Santos, 2003). At the Olhos de Água tracksite (Óbidos), theropod and ornithopod trackways of Aptian-Albian age were described by Mateus and Antunes (2003).

Table 1

Cretaceous dinosaur tracksites known in Portugal.

\begin{tabular}{|c|c|c|c|}
\hline Tracksite & Age & Trackmakers & References \\
\hline $\begin{array}{l}\text { Carenque-Pego } \\
\text { Longo }\end{array}$ & Cenomanian & $\begin{array}{l}\text { Theropoda and } \\
\text { ?Ornithopoda }\end{array}$ & $\begin{array}{l}\text { Santos et al. } \\
(1991,1992)\end{array}$ \\
\hline Olhos de Água & Aptian-Albian & $\begin{array}{l}\text { Theropoda and } \\
\text { Ornithopoda }\end{array}$ & $\begin{array}{l}\text { Mateus and } \\
\text { Antunes (2003) }\end{array}$ \\
\hline Praia Grande & Early Aptian & $\begin{array}{l}\text { Sauropoda, } \\
\text { Theropoda } \\
\text { and Ornithopoda }\end{array}$ & $\begin{array}{l}\text { Madeira and } \\
\text { Dias (1983); } \\
\text { Lockley et al. } \\
\text { (1994a); Santos } \\
\text { (2003) }\end{array}$ \\
\hline Santa & Early Barremian & $\begin{array}{l}\text { Ornithopoda } \\
\text { (Iguanodontia) }\end{array}$ & $\begin{array}{l}\text { Santos et al. } \\
\text { (2000a, b); } \\
\text { Santos (2003) }\end{array}$ \\
\hline Salema & Early Barremian & $\begin{array}{l}\text { Theropoda and } \\
\text { Ornithopoda } \\
\text { (Iguanodontia) }\end{array}$ & $\begin{array}{l}\text { Santos et al. } \\
\text { (2000a, b); } \\
\text { Santos (2003) }\end{array}$ \\
\hline Lagosteiros B & Hauterivian & $\begin{array}{l}\text { Theropoda and } \\
\text { ?Ornithopoda }\end{array}$ & $\begin{array}{l}\text { Antunes (1976); } \\
\text { Santos et al. (1992); } \\
\text { Meyer et al. (1994); } \\
\text { Santos (2003) }\end{array}$ \\
\hline Lagosteiros A & Berriasian & ?Theropoda & Santos (2003) \\
\hline
\end{tabular}

It is also worth mentioning the Cenomanian Carenque-Pego Longo tracksite, situated near Sintra, which is the only Late Cretaceous dinosaur tracksite known in Portugal. This tracksite consists of a long bipedal dinosaur trackway. It was the world's longest dinosaur trackway $(127 \mathrm{~m})$ when first described (Santos et al., 1991, 1992). It comprises a sequence of subcircular tracks that is reinterpreted herein on the basis of additional ichnological evidence resulting from a better understanding of its particular preservational features.

So far only two Early Cretaceous dinosaur tracksites are known in the Algarve Basin. These are near Vila do Bispo, $17 \mathrm{~km}$ to the west of Lagos (Fig. 1, Table 1). In 1995, dinosaur footprints were discovered for the first time in this onshore area by Carlos Coke during a geological fieldtrip (Santos et al., 2000a). At that time, seven small tridactyl and mesaxonic footprints were identified in the eastern sector of Salema beach. Subsequent discoveries at this beach include an ornithopod trackway identified by high-school children during a fieldtrip organized by Celestino Coutinho in 1996. In 1997, ornithopod trackways were found at Santa beach by Sebastião Pernes (Santos et al., 2000a).

In this paper we discuss the palaeobiological significance of the Iguanodontipus tracks and their association with specific marginalmarine depositional environments. At the same time, as a result of their location and age, these new findings also have implications for the palaeobiogeographical distribution presently assumed for the Early Cretaceous Iguanodontia of the Iberian Peninsula and southwestern Europe.

\section{Material and methods}

Non-metrical and metrical ichnological parameters were considered to characterize tridactyl tracks and trackways. The first provides indirect evidence of anatomical manus and foot features such as marks of pads and interdigital webs, heel shape and the shape of distal claws (rounded or sharp). The metrical parameters are: $L$, total footprint length; $W$, footprint width; $\lambda$, stride; $S$, step; TW, trackway width; $\gamma$, pace angulation. Two angular parameters are also considered: $\alpha$, angle measured between the axis of digits II and III; $\beta$, angle measured between the axis of digits III and IV (e.g., Leonardi, 1987; Moratalla et al., 1988; Thulborn, 1990; Lockley, 1991; Moratalla, 1993).

The measurements were made on each of the ornithopod tracks and trackways at the Santa and Salema tracksites using these parameters. The Salema tracksite initially yielded eight ornithopod footprints, but recent studies have led to the accumulation of new data and the description of at least 13 very lined-up footprints. Six footprints are clearly tridactyl and mesaxonic. The others have an almost subcircular shape and do not reveal any morphological features. At the Santa tracksite there is one main level with at least four trackways and also some isolated footprints in a total of 16 tracks.

It was considered important to make a cast of the best footprint assigned to the Iguanodontipus isp. discovered at the Santa tracksite, because this outcrop is being continually damaged by marine coastal erosion. This cast is part of the collections of the Museu Nacional de História Natural e da Ciência (Universidade de Lisboa), reference MNHN.UL.II 513.

\section{Geographical and geological settings}

The two Early Cretaceous dinosaur tracksites in the Algarve Basin (Santos et al., 2000a, b) are present in coastal exposures of the western sector, near the village of Salema (Vila do Bispo, southwest Algarve). They consist of two track levels preserved on the beach together with a set of three others at Santa beach, a small bay $2 \mathrm{~km}$ to the west (Fig. 2). 

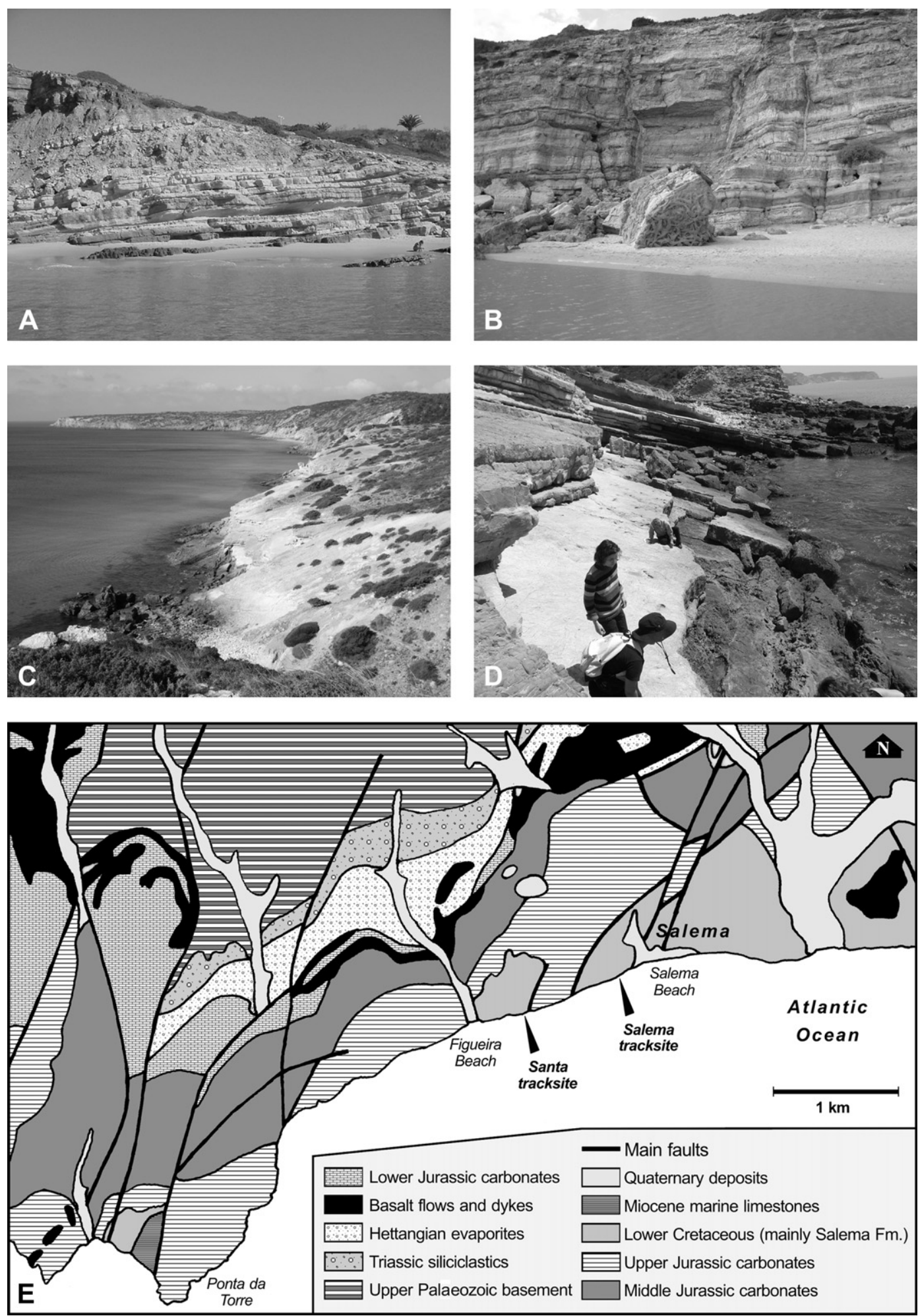

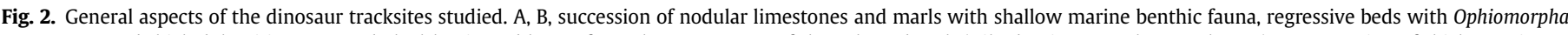

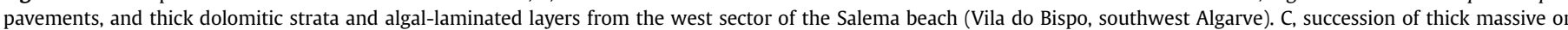

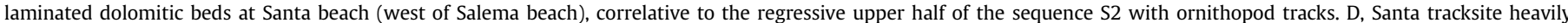

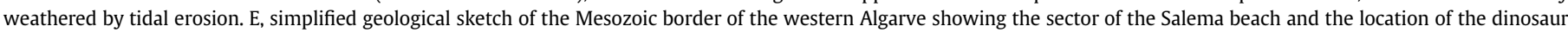

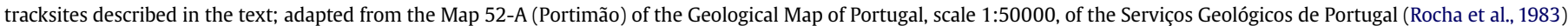

These areas with steep sea cliffs of limestone and massive dolomitic beds are at the western end of a nearly $15 \mathrm{~km}$ of continuous coastal exposures of Lower Cretaceous formations (Fig. 2). This succession is bounded to the east by Lower and Middle Miocene biocalcarenitic units (Lagos area), and by Middle and Upper Jurassic carbonates in the opposite direction (Sagres area).

Salema beach is a large sandy beach with easy access to the carbonate beds that crop out on the nearby slopes. The track levels 
are found on both sides of the beach, with emphasis on the ornithopod trackway set, which lies on massive beds on the western side near the wooden stairs used to access the cliff base. The succession exposed in this part of the section dips slightly towards the seashore and yields Choffatella-rich levels in the lower strata. At Santa beach there is a correlative succession of limestone and dolomitic beds that are steeply dipping towards the sea, allowing clear observation of bedding surfaces, some of which are bioturbated. Here, three dinosaur track levels were identified.

Both Salema and Santa beach successions containing the tracksites studied belong to the upper part of the Salema Formation (Rey, 1986, 2006a, 2010), an uppermost Hauterivian-Lower Barremian unit that correlates with the lower half of a thicker dolomitic succession of Barremian age, previously named "Margas, dolomias e calcários com Choffatella decipiens" Formation (Rey and Ramalho, 1973-1974; Rey, 1983). This designation was also used in the geological map of the area: Map 52-A (Portimão) of the Geological Map of Portugal, scale 1:50000, of the Serviços Geológicos de Portugal (Rocha et al., 1983). The lithology and micropalaeontological assemblages of this unit show many analogies with the "Calcários e margas com Choffatella" Formation known from the Upper Hauterivian-Lower Barremian of Cabo Espichel, Cascais and Ericeira, on the southern onshore part of the Lusitanian Basin (Rey, 1972, 2006b, 2010; Rey and Ramalho, 1973-1974).

From a sequence stratigraphical point of view, the Salema Formation records a regressive trend on the local and regional sedimentary settings. The succession begins with inner platform marine carbonates with diverse benthic microfauna, and gradually changes upwards to marginal-marine, inner-shelf carbonates with dolomitic beds, and mixed nearshore carbonate-siliciclastic lithofacies with a scarce brackish fauna of medium to low salinity biomarkers such as Glauconia and cerithoid gastropods. The dinosaur track levels occur in the upper half of this second-order sequence (Rey, 1986) as part of a succession of massive or ripplelaminated thick strata compatible with an Early Barremian tidalflat environment. The upper boundary of this unit is a basin-wide unconformity with a low angular discordance related to an intraBarremian tectono-sedimentary event that deformed earlier units of the active margin (Rey et al., 2006; Rey, 2010).

Besides this unconformity it is also relevant to note that the overall Cretaceous onshore record in the Algarve Basin, especially on its central and western sides, is comparatively more incomplete than the correlative succession of the adjacent Lusitanian Basin (Rey, 2006b, 2009, 2010; Dinis et al., 2008). The regional stratigraphical setting is almost restricted to the Berriasian-Aptian interval (Rey and Ramalho, 1973-1974; Rey, 1983), and marked by a scarcity of suitable biostratigraphical markers and several basinwide lacunas, including an extensive Upper Valanginian-Lower Hauterivian sedimentary gap (Rey, 1983). This rather incomplete stratigraphical succession dominated by shallow water facies clearly suggests a very marginal onshore record, as well as a basin history where tectonic events often masked the eustatic signature.

Fig. 3 illustrates a detailed section of the Salema cliffs (western side) in order to indicate precisely the stratigraphical and palaeo environmental settings of the ornithopod track level. The lower part of the succession with Chofatella concentrations is partly masked by modern beach sands, but the remaining fraction consists of $34 \mathrm{~m}$ of well-exposed beds organized in several parasequences and third-order sequences (S1-S4), showing an overall regressive trend. S1 consists of nodular limestones and marls with a shallow-water benthic fauna and regressive beds with Ophiomorpha pavements in the upper part of the sequence (Figs. 2A, B, 3). S2 is dominated by thick dolomitic beds, sometimes intercalated with algal-laminated layers. The main ornithopod track level lies at the top of bed 50. Dolomitic strata also prevail within the S3 sequence, but the thick beds of massive dolomite are less frequent and there is a small fauna of brackish molluscs. S4 also shows a transition to laminated marly strata with laminated algal layers and small molluscs that seem to indicate less restricted environmental conditions.

Finally, the succession exposed at Santa beach is reduced to several metres of thick massive or laminated dolomitic beds, which correlate with the regressive upper half of the S2 sequence where ornithopod footprints were identified at the Salema tracksite. There are also several beds with Ophiomorpha and bioturbation. Along this sedimentary sequence, dinosaur tracks were identified in three main track levels constituting the Santa tracksite described here, as well as at other levels showing scattered ornithopod footprints, isolated or in sets.

\section{Description of the Early Cretaceous ornithopod tracks}

\subsection{Salema tracksite}

In the western sector of Salema beach at the surface (Fig. 2A), there is a horizontal track level situated below the local school (Escola Básica do $1^{\circ}$ Ciclo de Salema) where a sequence of subcircular and tridactyl marks (SAL1-T1) was documented (Santos et al., 2000a, b; Santos, 2003). It is a trackway with at least 13 very lined-up footprints (the inner width of the trackway is almost zero) with a pace angulation value of about $170^{\circ}$ (Fig. 4). Although these impressions are quite degraded because of the constant marine erosion, we recognize six of them as clearly tridactyl and mesaxonic footprints. They are as long $(38 \mathrm{~cm})$ as wide $(37 \mathrm{~cm})$ and present short toes with rounded distal ends and symmetrical heel marks, like those attributed to ornithopod dinosaurs. The interdigital angles range from 30 to $40^{\circ}$. The other footprints are almost subcircular in shape and do not reveal any morphological features. Step values were measured on this trackway and it is notable that the step shortens. This is more obvious when the stride length is measured between the most distal points of digits III. The average step and stride values are about $70 \mathrm{~cm}$ and $1.4 \mathrm{~m}$ respectively.

Other track levels with theropod footprints are exposed along the cliff at Salema beach (Santos et al., 2000a; Santos, 2003), but their description is beyond the scope of this paper.

\subsection{Santa tracksite}

This tracksite, located at Santa beach, was discovered by Sebastião Pernes in 1997, and at that time two track levels were identified (Santos et al., 2000a, b). New discoveries were made during further fieldwork. Beatriz Oliveira identified a third track level $50 \mathrm{~cm}$ above the main one. More recently, to the east of this tracksite (Fig. 2C, D) Sebastião Pernes identified and photographed some new, isolated and paired, ornithopod footprints exposed at three other levels in the same sedimentary succession with Ophiomorpha burrows. Track level 1 at the Santa tracksite (SAN1) has an extensive intertidal exposure where the footprints are extremely eroded and all that exists today is evidence of dinoturbation and one isolated tridactyl track. It is longer $(75 \mathrm{~cm})$ than wide $(65 \mathrm{~cm})$. Toe prints II and III have a sharp distal end whereas toe print IV has a rounded distal end (Fig. 5A). Toe print III is slightly bent. The poorly preserved morphology of this track does not allow us to describe it better.

We have also seen poorly preserved crescent-shaped marks, which could be sauropod manus impressions. However, a problem arises here because the track level area is too confined to permit us to find a trackway. The tracks cannot be reliably attributed to sauropods because of the poor print morphology. Some marks are quite similar to sauropod manus prints, but erosion can produce 


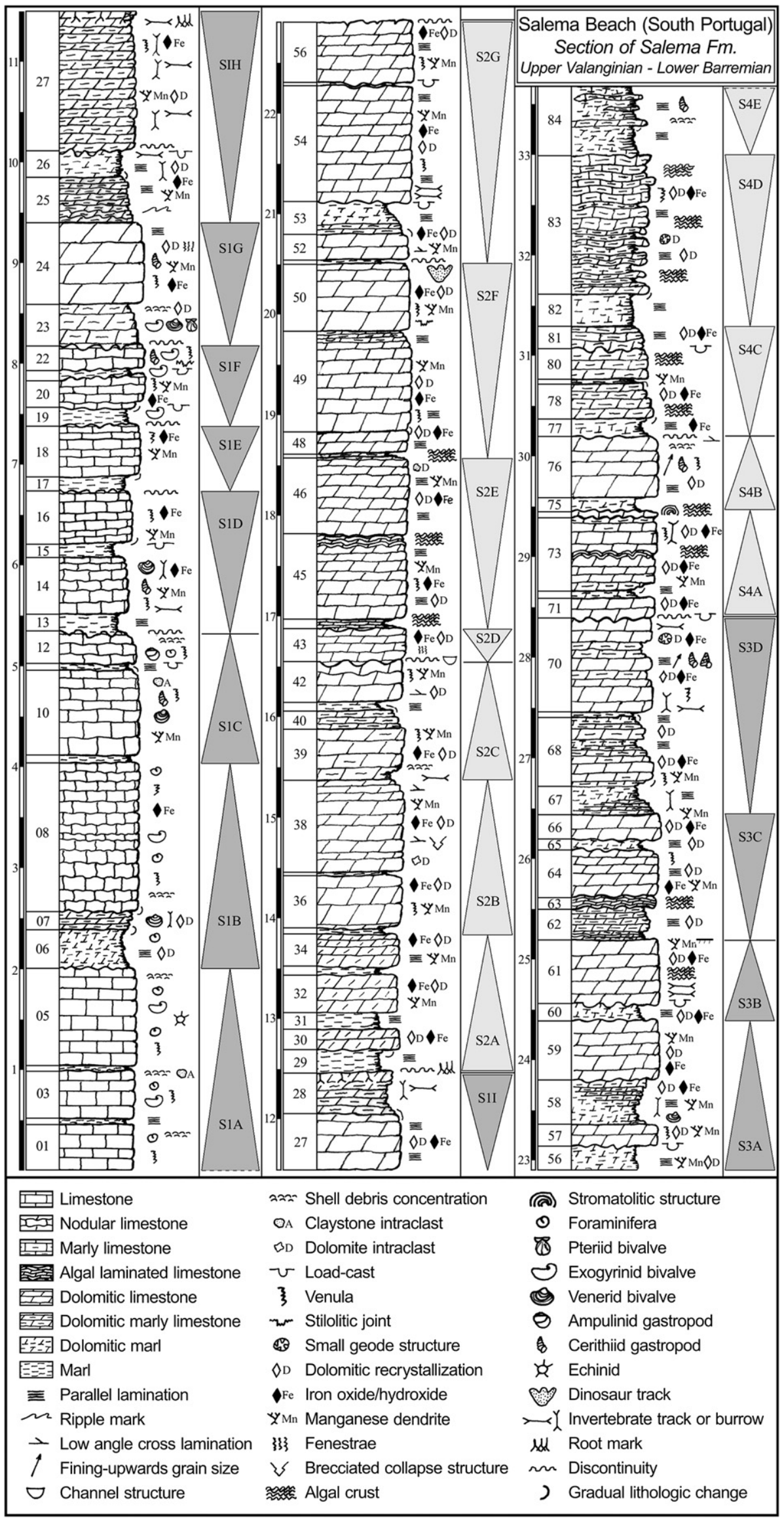

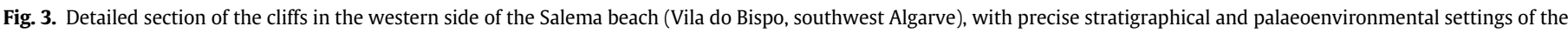
ornithopod track level. 


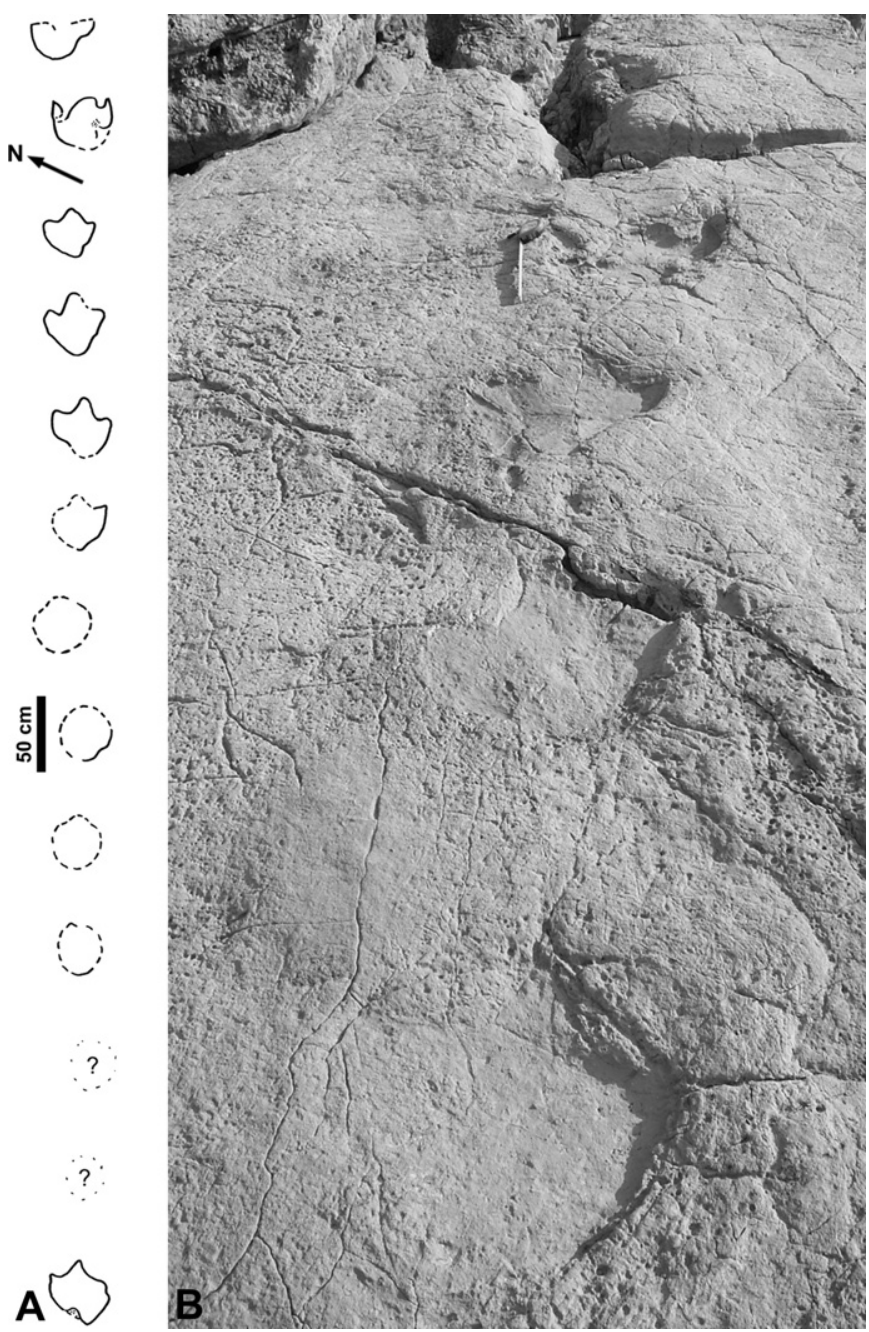

Fig. 4. Trackway of an ornithopod dinosaur at the Salema tracksite (Vila do Bispo, southwest Algarve). A, very lined-up sequence of tridactyl and subcircular impressions (SAL1-T1). B, photograph of a trackway segment.

strange morphologies. It is not prudent, therefore, to suggest the presence of these dinosaurs in the Algarve Basin during the Early Cretaceous based only on these marks. It is also possible to find circular marks defined by a groove, similar to a wrinkle, without a particular distribution pattern. We think that these may be atypical undertracks.

One metre above this dinoturbated level lies track level 2 (SAN2), which comprises at least four trackways and some isolated footprints. SAN2-1 is an isolated tridactyl and mesaxonic footprint, $30 \mathrm{~cm}$ long by $30 \mathrm{~cm}$ wide (Fig. 5B). It has a symmetrical and U-shaped heel mark and toe impressions with rounded distal ends.

Trackway 1 (SAN2-T1) is at the edge of this level and consists of four tridactyl and mesaxonic footprints, three of which are incompletely preserved (Fig. 5C). These footprints, $32 \mathrm{~cm}$ long by $26 \mathrm{~cm}$ wide, are rotated inward, have oval toe prints with rounded distal ends, and the last in the sequence has a symmetrical heel mark with two indentations. The interdigital angle values in these footprints are: $\alpha$, about $20^{\circ} ; \beta$, about $30^{\circ}$. The step and stride values are about $89 \mathrm{~cm}$ and $1.7 \mathrm{~m}$, respectively. The pace angulation value is about $140-150^{\circ}$.

Trackway 2 (SAN2-T2) is a sequence of six footprints, but only the first four are represented (Fig. 6A, B). The fifth print is underneath a block of rock that lies over track level 2 and has the same morphology as the others that are behind it. The last footprint is deformed, probably by the passage of another dinosaur whose trackway is not completely preserved. The first impression is partially preserved and represented by the dotted line in Fig. 6. In general, these footprints are slightly rotated inwards, with a form as long $(41 \mathrm{~cm})$ as wide $(39 \mathrm{~cm})$, and have a symmetrical heel mark with two indentations and oval toe prints with rounded distal ends. In the best-preserved footprint both interdigital angles are about $30^{\circ}$. The step and stride values are about 1 and $1.9 \mathrm{~m}$, respectively. The pace angulation value is about $130-140^{\circ}$.

There are at least two other trackways (SAN2-T3 and SAN2-T4) with a similar footprint morphology and the same trackway pattern as SAN2-T2 (Fig. 6C). The step and stride values are about 1.2 and $2.3 \mathrm{~m}$, respectively. The pace angulation value is about $140-147^{\circ}$.

At this tracksite it is possible to recognize the characteristic morphology of ornithopod footprints in trackways 1 (Fig. 5C), 2 (Fig. 6A, B), 3 and 4 (Fig. 6C).

Other poorly preserved subcircular and crescent-shaped impressions can be recognized on this track level, but they do not have morphological characteristics that support trackmaker identifications and we cannot find a revealing trackway pattern.

About $50 \mathrm{~cm}$ above the main track level is another surface (SAN3) with dinosaur tracks. This third track surface is barely visible. Through a small space left by differential erosion of the marly bed $15 \mathrm{~cm}$ thick that overlies it, it is possible to identify a sequence of apparently rounded impressions and one isolated small tridactyl and mesaxonic footprint impression $(12 \mathrm{~cm}$ long by almost $10 \mathrm{~cm}$ wide and slender toe prints) of an undetermined biped dinosaur.

\section{Discussion}

There are several aspects of the Santa tracksite to be pondered. According to the dinoturbation index proposed by Lockley and Conrad (1989) and Lockley (1991), we consider that track level 1 (SAN1) is an area of moderate dinosaur trampling. The long exposure to tidal erosion has left only one footprint with a poorly preserved morphology (Fig. 5A). This morphology might suggest a theropod trackmaker if a close look is taken at the sharp distal ends of toes II and III and the slightly bent toe print III. However, owing to its poor preservation, there are insufficient characters to distinguish it as either a theropod or an ornithopod footprint. Thus, we prefer to assign this track to an undetermined biped dinosaur.

Track level 2 (SAN2) consists of footprints with inward rotation that are characterized by being almost as long as wide, and in having a symmetrical U-shaped heel mark with two indentations, and short and wide toe marks (oval shaped) with rounded distal ends (Fig. 6B). The morphological and stratigraphical resemblance of these footprints to those of the ichnogenus Iguanodontipus from the Berriasian of Dorset (southern England) and defined by Sarjeant et al. (1998) is remarkable, so we attribute them to the same ichnogenus.

There are some Early Cretaceous tracksites in the Iberian Peninsula from which ornithopod tracks have been described. Footprints most similar to those of the Santa beach track record were described by Moratalla and Hernán (2008) at the Los Cayos tracksite (Cornago, La Rioja, Spain) of Barremian-Early Aptian age, and Pascual-Arribas et al. (2009) at the Las Cuestas I tracksite (Santa Cruz de Yanguas, Soria, Spain) of Berriasian age. Both were assigned to the ichnogenus Iguanodontipus. Trackway STC-1 (Pascual-Arribas et al., 2009, fig. 4) specially resembles trackway 2 (SAN2-T2) of the main level at the Santa tracksite, here attributed to Iguanodontipus isp.

There are other European Early Cretaceous tracksites with ornithopod footprints attributed to Iguanodontipus isp. with a widespread temporal distribution throughout the Early 


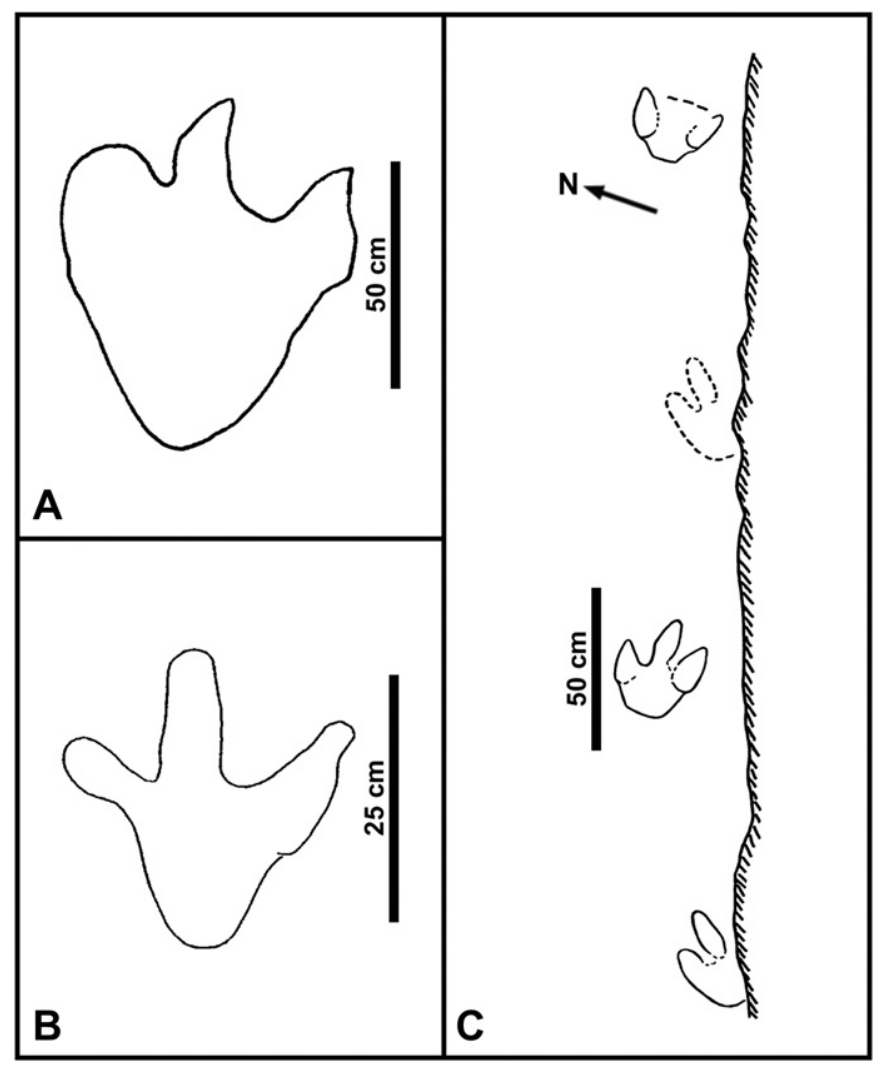

Fig. 5. Tridactyl tracks from the Santa tracksite (Vila do Bispo, southwest Algarve) A, left footprint of an undetermined biped dinosaur (SAN1-1) recognized in track level 1 with dinoturbation. $B$, a possible ornithopod isolated footprint at the main track level (SAN2-1). C, trackway 1 (SAN2-T1) with one well-preserved tridactyl footprint from the main track level (modified from Santos, 2003).

Cretaceous, i.e., from Berriasian to Late Aptian (Table 2). Wings et al. (2005) reported the existence of five trackways in the Berriasian of Münchehagen (northern Germany) and assigned them to Iguanodontipus. This ichnogenus was also identified in Wealden strata at
Table 2

Early Cretaceous European dinosaur tracksites (except the Portuguese ones) with the ichnogenus Iguanodontipus. *Iguanodontipus holotypes.

\begin{tabular}{|c|c|c|c|}
\hline Tracksite & Age & Location & References \\
\hline Risleten quarry & Late Aptian* & Switzerland & $\begin{array}{l}\text { Meyer and } \\
\text { Thüring (2003) }\end{array}$ \\
\hline Los Cayos & $\begin{array}{l}\text { Barremian-Early } \\
\text { Aptian }\end{array}$ & Spain & $\begin{array}{l}\text { Moratalla and } \\
\text { Hernán (2008) }\end{array}$ \\
\hline $\begin{array}{l}\text { Lee Ness, Cooden } \\
\text { and Hanover } \\
\text { Point }\end{array}$ & $\begin{array}{l}\text { Valanginian-Early } \\
\text { Aptian }\end{array}$ & England & Goldring et al. (2005) \\
\hline Münchehagen & Berriasian & Germany & Lockley et al. (2004) \\
\hline Münchehagen & Berriasian & Germany & Wings et al. (2005) \\
\hline Obernkirchen & Berriasian & Germany & Diedrich (2004) \\
\hline Las Cuestas I & Berriasian & Spain & $\begin{array}{l}\text { Pascual-Arribas } \\
\text { et al. (2009) }\end{array}$ \\
\hline Dorset & Berriasian* & England & Sarjeant et al. (1998) \\
\hline
\end{tabular}

Lee Ness and Cooden in south-east England and Hanover Point on the Isle of Wight (Valanginian-Lower Aptian) by Goldring et al. (2005). Other ornithopod trackways with a general morphology that resembles the Santa beach track record were described by Diedrich (2004) from the Obernkirchen tracksite in the Berriasian of northwest Germany. Meyer and Thüring (2003) also reported ornithopod tracks of Late Aptian age from the Schrattenkalk Formation of the Swiss Central Alps, in Risleten quarry, and attributed them to iguanodontids. However, these differ in the general morphology from the Santa beach track record. The ornithopod footprints at Santa beach resemble some of the Berriasian ornithopod tracks at Dinosaurier Freilichtmuseum Münchehagen (Germany), which occur as natural casts and were described by Lockley et al. (2004), who thought they might be referred to Iguanodontipus.

In the Late Jurassic track record of Europe there are some iguanodontid-like footprints of uncertain affinity, such as those from Portugal (Mateus and Milàn, 2005, 2008), Spain (Piñuela Suárez, 2000; García-Ramos et al., 2002) and Germany (Diedrich, 2011). As these tracks do not have morphological characteristics that allow their confident assignation to Iguanodontipus, and because it is also possible that they were not made by an
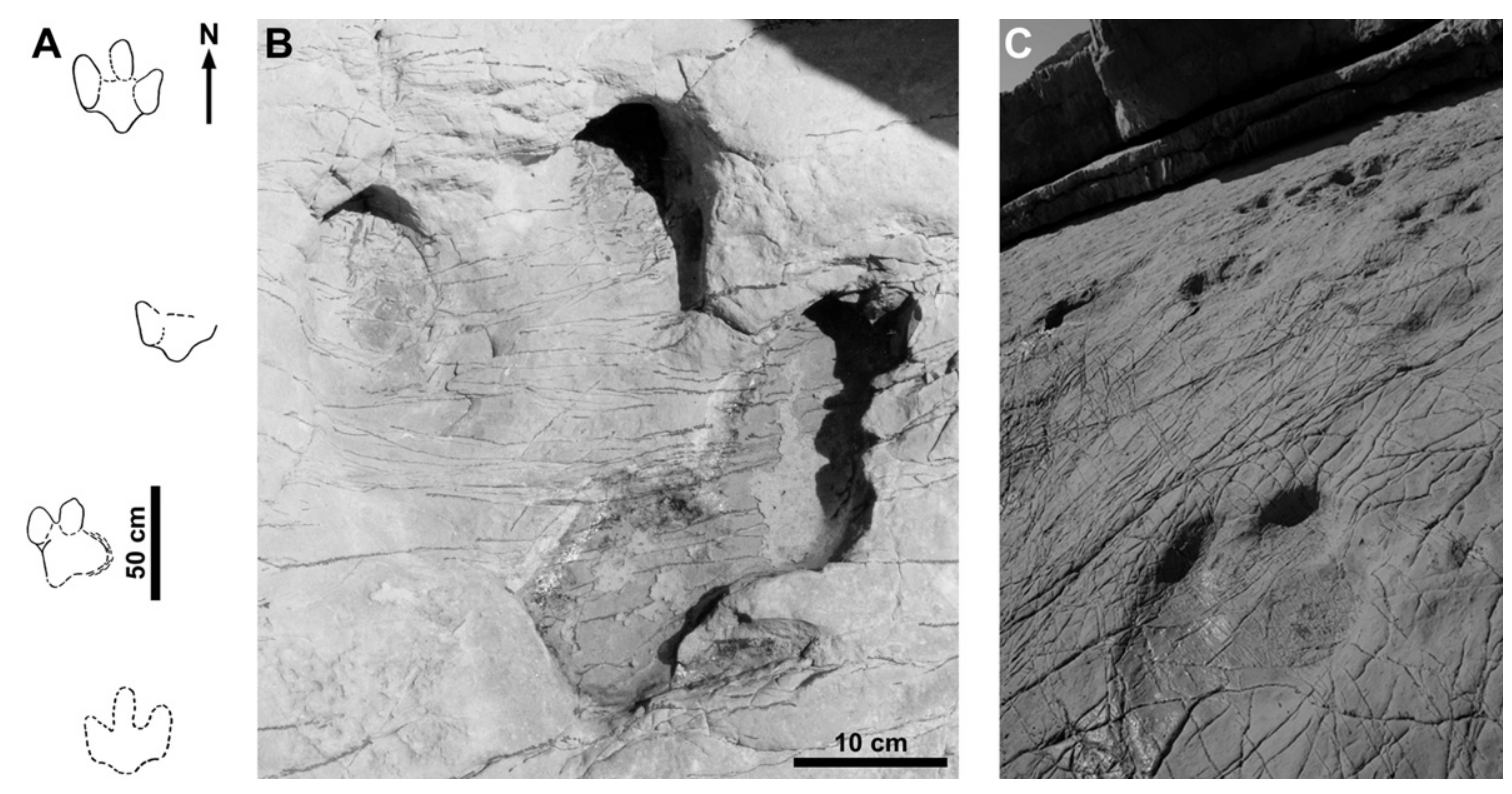

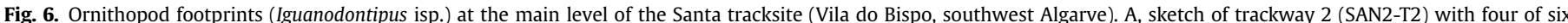

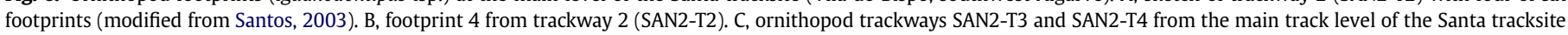
(photograph by Luís Quinta). 
iguanodontian dinosaur, we consider that they differ from the track record of the Santa tracksite attributed to this ichnogenus.

The morphological features of the footprints from the Santa tracksite (Figs. 5B, C, 6) allow its attribution to Iguanodontipus and suggest iguanodontian dinosaur trackmakers (Iguanodontia). These dinosaurs would have had posterior limbs with a hip height of about 1.8 to $2.4 \mathrm{~m}$ and moved at speeds ranging between 3.1 and $4.4 \mathrm{~km} / \mathrm{h}$, based on the equations of Alexander (1976).

The study of the European Early Cretaceous basal iguanodonts is in continuous review and quite a few osteological remains assigned to Iguanodon have been reassigned to new genera (e.g., Norman, 2002, 2004, 2010; Norman and Barrett, 2002; Paul, 2006, 2008; Naish and Martill, 2008; Galton, 2009; Carpenter and Ishida, 2010; McDonald et al., 2010; McDonald, 2012).

Ornithopod remains have been known in Portugal since the nineteenth century in the coastal cliffs of Boca do Chapim, to the north of Cabo Espichel, near Sesimbra (see Rodrigues et al., 2008 for a historical review of the vertebrate fauna of this site). These earliest discoveries were reported by Sauvage (1896, 1897-1898, 1898). Iguanodon mantelli Meyer, 1832 was recognized by this author and its presence was later confirmed by de Lapparent and Zbyszewski (1957). Galton (1994) provided a new description of these ornithopod remains and assigned them to Iguanodon sp. Since then, a few publications about the dinosaurs of Boca do Chapim have appeared in which their taxonomy is reviewed. For example, Ruiz-Omeñaca and Canudo $(2003,2004)$ confirmed that the ornithopod remains at this site belong to Iguanodon sp. and Antunes and Mateus (2003) supported this assignation.

In Spain, ornithopod osteological remains from several provinces were attributed traditionally to the genus Iguanodon and to Iguanodontidae indet. or Iguanodontoidea indet. (e.g., RuizOmeñaca et al., 1998, 2004, 2009; Ruiz-Omeñaca and Canudo, 2003, 2004; Torcida Fernández-Baldor et al., 2006; ContrerasIzquierdo et al., 2009; Ruiz-Omeñaca, 2011). Recent studies have led to the description and assignation of these ornithopod remains to the clade Iguanodontoidea non-Hadrosauridae (sensu Norman, 2002, 2004). Ruiz-Omeñaca and Canudo (2003) presented a comprehensive synthesis of the ornithischian dinosaurs from the Lower Cretaceous (Hauterivian-Aptian) of the Iberian Peninsula, referring to the existence of remains of hypsilophodontids, dryosaurids, iguanodontids, possible heterodontosaurids and ?hadrosauroids. Iguanodon bernissartensis Boulenger, 1881 and Delapparentia turolensis Ruiz-Omeñaca, 2011 from the Spanish Lower Cretaceous dinosaur osteological record are accepted as Iguanodontoidea species (e.g., Sanz et al., 1982; Gasulla et al., 2009; Ruiz-Omeñaca, 2011). The synthesis presented by Ortega et al. (2006) considered that ornithopods like hypsilophodontids, dryosaurids and iguanodontids (Iguanodon) are represented in the Lower Cretaceous of the Iberian Peninsula and that Iguanodon, represented by Iguanodon bernissartensis, was probably the most common dinosaur in Barremian and Aptian times. Recently, Norman (2010) presented a review of the history, anatomy and taxonomy of the Hauterivian-Early Aptian iguanodontian dinosaurs from southern England and concluded that the Upper Wealden Group (Hauterivian-Lower Aptian) contains evidence of Iguanodon bernissartensis and Mantellisaurus atherfieldensis. Therefore, according to these data, dinosaurs like Iguanodon and Delapparentia or other taxa that can be determined based on classic or new material, are possible trackmakers of the ichnogenus Iguanodontipus. Thus, we conclude that the footprints at the Santa tracksite, assigned to Iguanodontipus, were quite possibly made by one of these ornithopod dinosaurs.

Santa beach track level 3 (SAN3) shows dinoturbation and there is evidence of a small undetermined bipedal dinosaur, but we cannot discard the possibility of an ornithopod or theropod affinity.

The most interesting ichnological feature in the western sector of Salema beach is the trackway SAL1-T1 with at least six tridactyl footprints, as long as wide, plus four subcircular impressions without toe marks (Fig. 4). Although they have been tridactyl tracks, like the others, marine erosion has degraded them. The

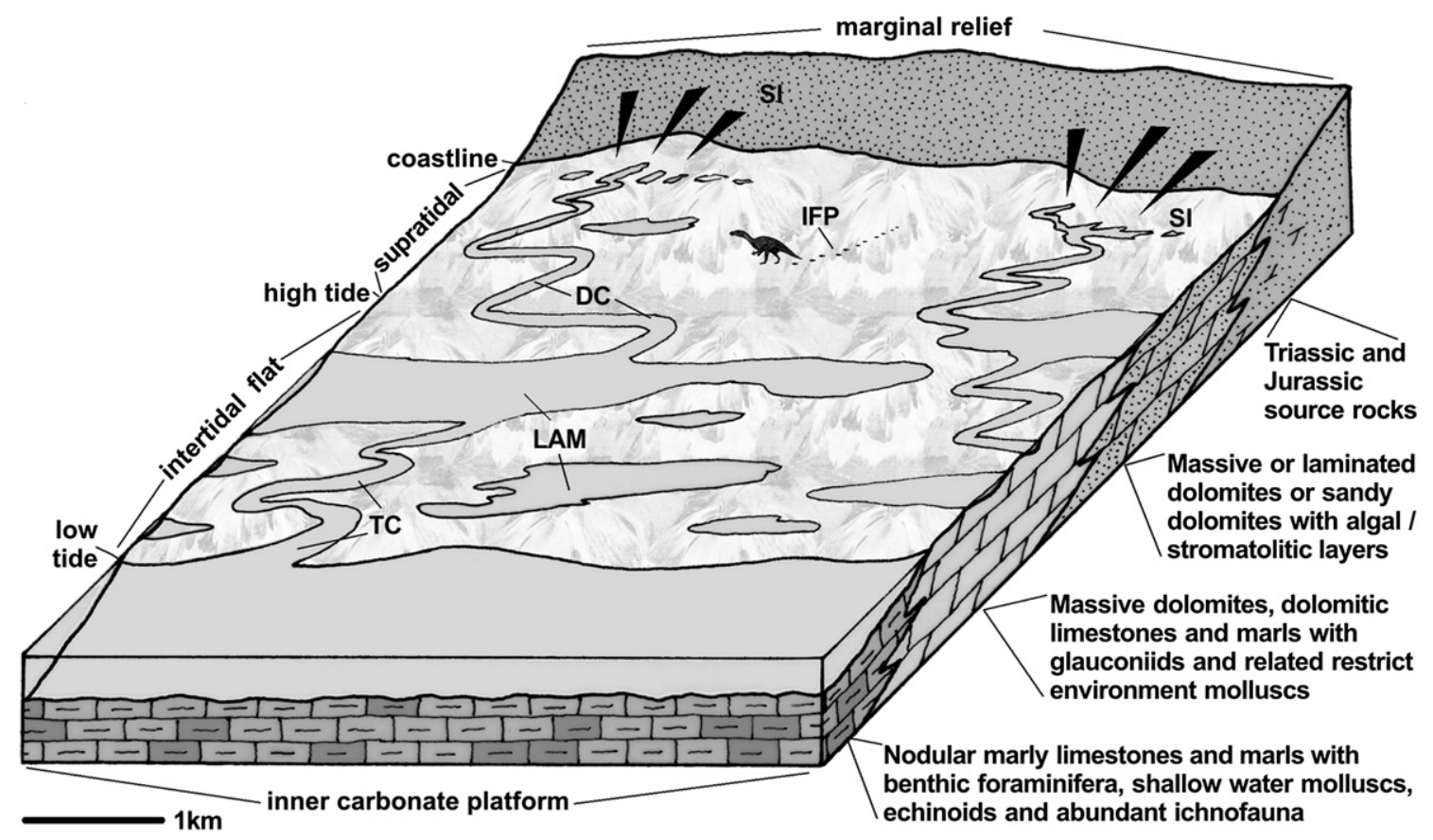

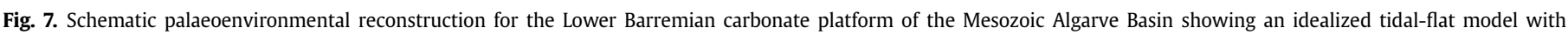

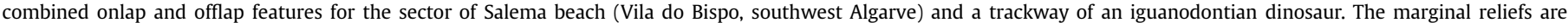

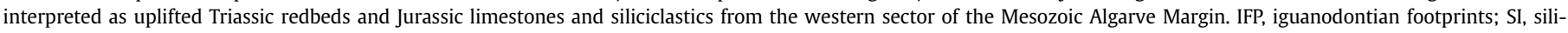
ciclastic influx; DC, distributary channels; LAM, laminated algal mats and restricted lagoons; TC, tidal channels with seawater influx. 
morphology of the best-preserved tridactyl impressions allows us to attribute them to an ornithopod, possibly an iguanodontian dinosaur with a hip height of about $2.2 \mathrm{~m}$ that could have been moving at $1.7 \mathrm{~km} / \mathrm{h}$, based on Alexander's (1976) equations. This trackway was the first evidence of well-preserved ornithopod dinosaur footprints in Portugal (Santos et al., 2000b).

The variation in footprint morphology observed along this trackway demonstrates that characteristic ornithopod footprints can be transformed into subcircular impressions when exposed to erosion or if they are not preserved as true tracks (sensu Lockley, 1991). Therefore, this particular trackway shows how erosion changes track morphology and allows the attribution of subcircular impressions at least to ornithopod footprints. Where preservation state does not change the value of pace angulation and the high pace angulation value indicates bipedal trackways (e.g., Santos et al., 1992), we can conclude that a sequence of subcircular tracks having a pace angulation of high value can almost certainly be assigned to an ornithopod trackmaker.

Several authors have brought to light new data from controlled laboratory track simulations in order to understand better the effects of erosion on the size and morphology of dinosaur tracks, as well as to evaluate how the shape of the footprint deteriorates with depth in different substrates (e.g., Gatesy et al., 1999; Gatesy, 2003; Milàn et al., 2004; Henderson, 2006; Milàn, 2006; Milàn and
Bromley, 2006; Manning, 2008; Jackson et al., 2009; Marty et al., 2009). The variation in footprint morphology along the trackway at the Santa tracksite reveals how an ornithopod footprint can become a rounded track. With this example it is clear that footprints attributed to iguanodontians can be subcircular in shape since they were originally as wide as long. The ornithopod trackway at the Salema tracksite with subcircular and tridactyl impressions is important for understanding sequences of subcircular impressions with a high pace angulation value in the track record, such as those at the Carenque-Pego Longo (Sintra) and Lagosteiros (Cabo Espichel, Sesimbra) tracksites (Santos et al., 1992). Thus, the ornithopod track record from the onshore southwest Algarve Basin also supports the interpretation that the main trackways at these sites were very likely to have been made by bipedal ornithopods, such as iguanodontian dinosaurs. Therefore, taking into account information presented in these earlier publications, iguanodontians were probably one of the commonest dinosaurs in the Iberian Peninsula during the Barremian-Aptian period.

From a palaeoecological point of view, the composition of the facies suggests that the dinosaur tracks in the southwest Algarve Basin were produced in a marginal-marine environment (Fig. 7) where a large tidal flat associated with the inner shelf of a nearby carbonate platform was periodically exposed (Shinn, 1983). The warm and dry local climate also favoured the deposition of

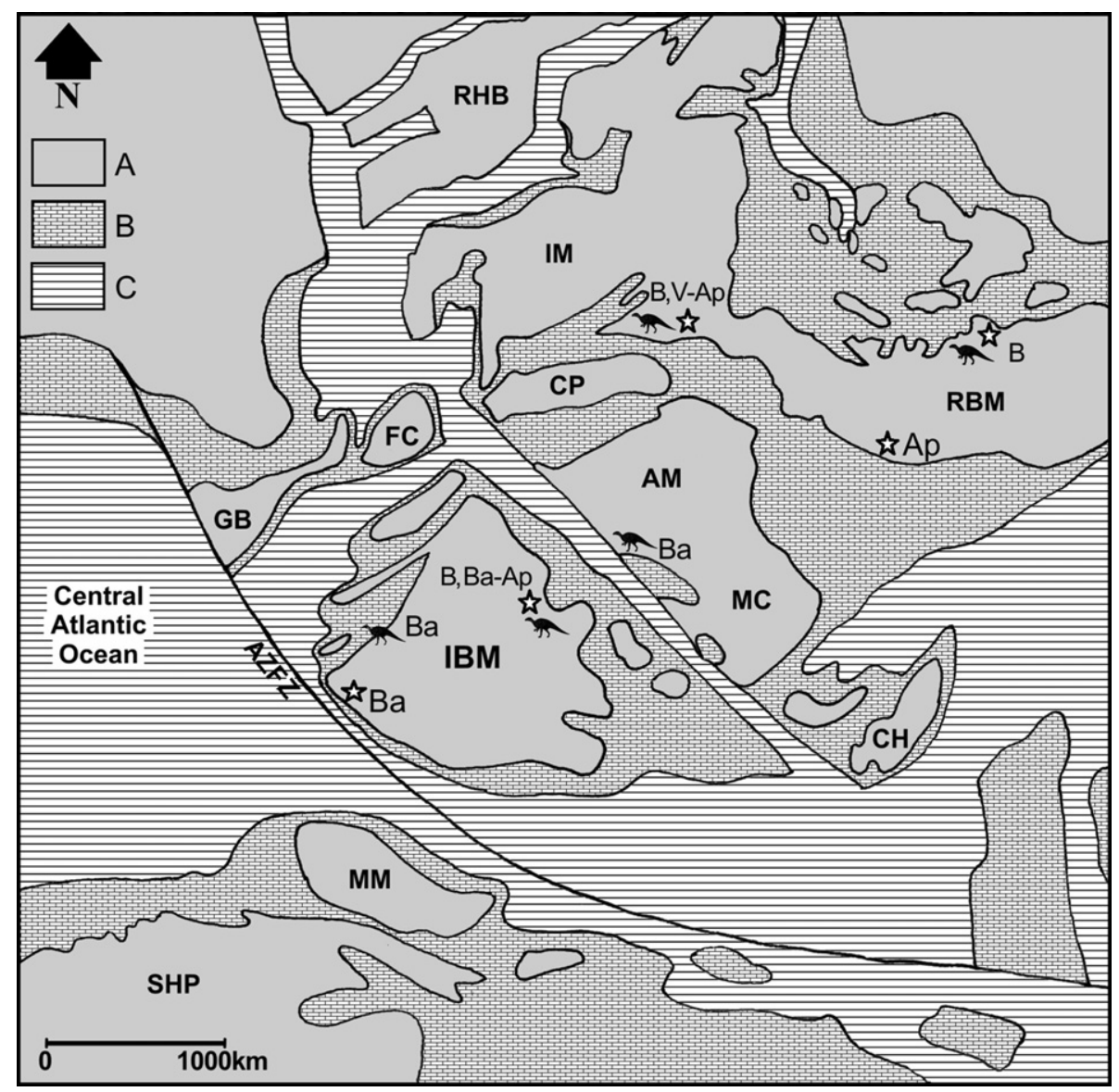

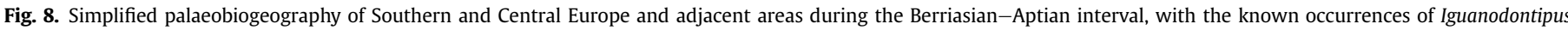

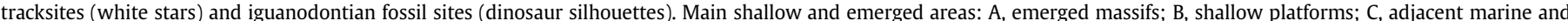

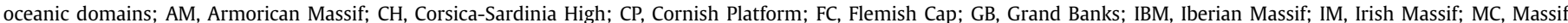

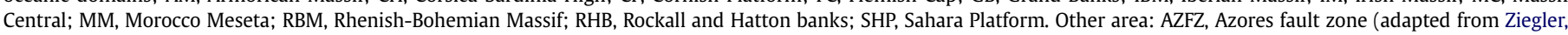

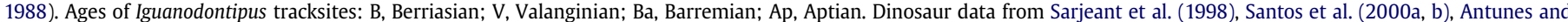

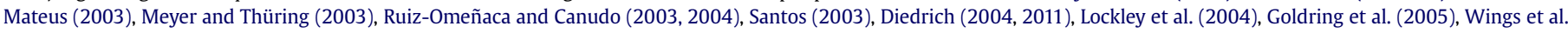
(2005), Moratalla and Hernán (2008), Pascual-Arribas et al. (2009). 
intertidal and upper infralittoral dolomitic sediments, much as in modern sabkha environments (McKee and Ward, 1983). The abundance of algal-laminated layers interbedded with massive levels of dolomite can also be related to the existence of algal mats in channels and ponds within the tidal flat.

The occurrence of iguanodontian dinosaur footprints in the Algarve Basin also indicates that these ornithopod dinosaurs had an Early Barremian biogeographical range that extended to the south of the Iberian Massif (Fig. 8). Nevertheless, there are previous records of Iguanodontipus tracks in the north of Spain at least from the Berriasian (Pascual-Arribas et al., 2009; Castanera et al., 2012), suggesting that this group of dinosaurs appeared no later than the beginning of the Cretaceous Period in the Iberian Massif as a result of coastal migration across the nearby European islands of the Armorican, Central, Irish and Rhenish-Bohemian massifs, where iguanodontian dinosaurs and footprints of this age have also been recorded (Diedrich, 2004; Lockley et al., 2004; Goldring et al., 2005; Wings et al., 2005). These coastal routes that allowed the interchange of land species between emerged areas of the Central Europe and those from the Tethyan branch of the Southern Europe were mainly open during intervals of eustatic low stands, when a general progradation of landward sedimentary systems led to large intertidal-flat domains, sometimes acting as episodic bridges (Diedrich, 2011). The growing number of new finds confirms that these land bridges would have existed periodically depending on local geotectonic evolution, despite the more or less extensive submerged areas that separated the European massifs during the Early Cretaceous (Dalla Vecchia, 2002; Meyer and Thüring, 2003; Gheerbrant and Rage, 2006).

The possibility of an additional intercontinental land bridge between southern Iberia and the North African domains of Gondwana seems unlikely before the Late Barremian-Early Aptian because of the divergent geotectonic settings for most of the "Neocomian" and different dinosaur faunas in these two continental areas (Canudo et al., 2009). The tidal-flat and carbonate inner-shelf domains reported for the Algarve Basin were, therefore, directly connected to the open ocean and did not allow any landvertebrate migrations. Nevertheless, several authors have supported the possibility of the existence of a route across the Apulian Plate (Nicosia et al., 2007; Petti et al. 2008; Sacchi et al., 2009; Torcida Fernández-Baldor et al., 2011) at least since the Late Barremian and during the Aptian (Canudo et al., 2009), when shallow carbonate shelves were widespread between this area and North Africa. A better understanding of European ornithopod palaeo biogeography is needed to determine whether or not this interpretation can be substantiated.

\section{Conclusions}

Fieldwork in the southwest Algarve Basin has led to the first dinosaur track discoveries in this area. Well-preserved iguanodontian footprints have been described for the first time in Portugal and Iguanodontipus isp. was identified at the Santa tracksite. The existence of several track levels along the sedimentary sequence described here with ornithopod tracks suggests that this dinosaur group was well-represented in the Iberian Peninsula and southwestern Europe during the Early Cretaceous. We regard this as compelling evidence of the frequent occurrence of Iguanodon in Portugal, thus supporting the recovery of isolated and fragmentary remains of this dinosaur (five isolated teeth and few caudal vertebrae) from Boca do Chapim.

The trackways of the Santa tracksite reveal the presence of iguanodontian dinosaurs having posterior limbs with a hip height of $1.8-2.4 \mathrm{~m}$ that moved at speeds ranging from 3.1 to $4.4 \mathrm{~km} / \mathrm{h}$. Iguanodon, Delapparentia or other still unidentified or undescribed taxa from the Iberian Peninsula are the possible trackmakers of the footprints assigned to the ichnogenus Iguanodontipus and in this case the footprints from the Santa tracksite.

A single trackway at the Salema tracksite that comprises subcircular and tridactyl impressions attributed to an ornithopod, a possible iguandontian dinosaur, shows that ornithopod footprints, being as long as wide tridactyl impressions, result in subcircular impressions when they are eroded. Since it is known that a biped dinosaur trackway is characterized by having a high pace angulation value, we conclude that a sequence of subcircular footprints having a high value of pace angulation can almost certainly be assigned to an ornithopod trackmaker. This is a very significant record regarding trackmaker identification, when very lined-up sequences of subcircular footprints are found, such as those of the Carenque-Pego Longo and Lagosteiros tracksites in the Lusitanian Basin.

These dinosaur trackways are preserved in marginal-marine carbonate sediments of a large inner-shelf environment with shoals and intertidal-flat areas with algal mats, tidal channels and ponds, somewhat restricted brackish conditions, and dolomitic sedimentation related to a warm and dry climate.

The occurrence of this iguanodontian evidence also has implications for the palaeobiogeography of the group, because it shows that the Southern European range of these ornithopod dinosaurs reached the south of the Iberian Massif during the Early Barremian. This became possible after one or more earlier migratory events took place after the Berriasian, which are welldocumented by records of Iguanodontipus tracks in the north of Spain. The successful opening of coastal bridges between Iberia and the nearby European emerged massifs was thus possible, but the hypothesis of an intercontinental route between Iberia and North Africa seems very unlikely, at least during the "Neocomian".

\section{Acknowledgements}

This study was funded by FCT (Fundação para a Ciência e a Tecnologia) through the POCI/CTE-GEX/58415/2004 Project (Survey and Study of Middle Jurassic through Late Cretaceous Terrestrial Vertebrates from Portugal: implications in paleobiology, paleoecology, evolution and stratigraphy) from the Museu Nacional de História Natural and through the PEst-OE/CTE/UI0611/2012 Project from the Centro de Geofísica da Universidade de Coimbra. We thank António Calixto, Beatriz Oliveira, Carlos Coke, Carlos Silva, Celestino Coutinho, Gonçalo Pereira, Hugo Fernandes, Joana Revez, José Luís D’Orey, Luís Quinta, Luís Rodrigues, Margarida Agostinho, Maria do Carmo Ramalho, Pedro Terrinha and Sebastião Pernes for their support in the field. We also thank José Carlos García-Ramos and Laura Piñuela Suárez for their comments on a draft of this manuscript, as well as Alberto Cobos, Diego Castanera, Guadalupe Jácome, Ignacio Díaz Martínez, José Jácome and an anonymous reviewer for important and helpful comments that have clearly improved this paper. We are especially grateful to David Batten for his careful help with the final review of the manuscript.

\section{References}

Alexander, R.M., 1976. Estimates of speeds of dinosaurs. Nature 261, 129-130. Antunes, M.T., 1976. Dinosáurios Eocretácicos de Lagosteiros. Ciências da Terra (UNL) 1, 1-35.

Antunes, M.T., Mateus, O., 2003. Dinosaurs of Portugal. Comptes Rendus Palevol 2, 77-95.

Canudo, J.I., Barco, J.L., Pereda-Suberbiola, X., Ruiz-Omeñaca, J.I., Salgado, L., Torcida Fernández-Baldor, F., Gasulla, J.M., 2009. What Iberian dinosaurs reveal about the bridge said to exist between Gondwana and Laurasia in the Early Cretaceous. Bulletin de la Société Géologique de France 180, 5-11.

Carpenter, K., Ishida, Y., 2010. Early and "middle" Cretaceous iguanodonts in time and space. Journal of Iberian Geology 36, 145-164. 
Castanera, D., Pascual, C., Canudo, J.I., Hernández, N., Barco, J.L., 2012. Ethological variations in gauge in sauropod trackways from the Berriasian of Spain. Lethaia. http://dx.doi.org/10.1111/j.1502-3931.2012.00304.x.

Contreras-Izquierdo, R., Cruzado-Caballero, P., Torcida Fernández-Baldor, F., Huerta, P., Izquierdo Montero, L.A., Montero Huerta, D., Pérez Martínez, G. Urién Montero, V., 2009. Un ilion de un dinosaurio "iguanodóntido" procedente del Cretácico Inferior de Burgos (España). In: Huerta Hurtado, P., Torcida Fernández-Baldor, F. (Coords.), Actas de las IV Jornadas Internacionales sobre Paleontología de Dinosaurios y su Entorno, Salas de los Infantes, Burgos, Spain, 13-15 de septiembre de 2007, pp. 187-195.

Dalla Vecchia, F.M., 2002. Cretaceous dinosaurs in the Adriatic-Dinaric Carbonate Platform (Italy and Croatia): paleoenvironmental implications and paleogeographical hypotheses. Memoria della Società Geologica Italiana 57, 89-100.

Diedrich, C., 2004. New important iguanodontid and theropod trackways of the tracksite Obernkirchen in the Berriasian of NW Germany and megatracksite concept of Central Europe. Ichnos 11, 215-228.

Diedrich, C., 2011. Upper Jurassic tidal flat megatracksites of Germany - coastal dinosaur migration highways between European islands, and a review of the dinosaur footprints. Palaeobiodiversity and Palaeoenvironments 91, 129-155.

Dinis, J.L., Rey, J., Cunha, P.P., Callapez, P., Pena dos Reis, R., 2008. Stratigraphy and allogenic controls on the western Portugal Cretaceous: an updated synthesis. Cretaceous Research 29, 772-780.

Galton, P.M., 1994. Notes on Dinosauria and Pterodactylia from the Cretaceous of Portugal. Neues Jahrbuch für Geologie und Paläontologie, Abhandlungen 194, 253-267.

Galton, P.M., 2009. Notes on Neocomian (Lower Cretaceous) ornithopod dinosaurs from England - Hypsilophodon, Valdosaurus, "Camptosaurus", "Iguanodon" and referred specimens from Romania and elsewhere. Revue de Paléobiologie $28,211-273$.

García-Ramos, J.C., Lires, J., Piñuela Suárez, L., 2002. Dinosaurios: Rutas por el Jurásico. Grupo Zeta, La Voz de Asturias, Lugones, Spain, 204 pp.

Gasulla, J.M., Sanz, J.L., Ortega, F., Escaso, F., 2009. Iguanodon bernissartensis from the Early Aptian of Morella (Castellón, Spain). In: Godefroit, P., Lambert, O. (Eds.), Programme, Abstracts and Field Trips Guidebook of the Tribute to Charles Darwin and Bernissart Iguanodons: New Perspectives on Vertebrate Evolution and Early Cretaceous Ecosytems, Brussels, Belgium, February 9-13, 2009, p. 44.

Gatesy, S.M., 2003. Direct and indirect track features: What sediment did a dinosaur touch? Ichnos 10, 91-98.

Gatesy, S.M., Middleton, K.M., Jenkins Jr., F.A., Shubin, N.H., 1999. Three-dimensional preservation of foot movements in Triassic theropod dinosaurs. Nature 399, 141-144.

Gheerbrant, E., Rage, J.C., 2006. Paleobiogeography of Africa: How distinct from Gondwana and Laurasia? Palaeogeography, Palaeoclimatology, Palaeoecology 241, 224-246.

Goldring, R., Pollard, J.E., Radley, J.D., 2005. Trace fossils and pseudofossils from the Wealden strata (non-marine Lower Cretaceous) of southern England. Cretaceous Research 26, 665-685.

Henderson, D.M., 2006. Simulated weathering of dinosaur tracks and the implications of their characterization. Canadian Journal of Earth Sciences 43, 691-704.

Jackson, S.J., Whyte, M.A., Romano, M., 2009. Laboratory-controlled simulations of dinosaur footprints in sand: a key to understanding vertebrate track formation and preservation. Palaios 24, 222-238.

Kasprak, A.H., Whiteside, J.H., Lopes, F.M., Brusatte, S.L., Butler, R.J., Mateus, O., 2010. New paleoenvironmental and biotic records from the Triassic-Jurassic boundary interval of the Algarve Basin, Portugal. In: American Geophysical Union, Fall Meeting, San Francisco, California, December 13-17, 2010. Eos Transactions 91 (Supplement), Abstract \#B51F-0410.

de Lapparent, A.F., Zbyszewski, G., 1957. Les dinosauriens du Portugal. Mémoires des Services Géologiques du Portugal, Nouvelle Série 2, 1-63.

Leonardi, G. (Ed.), 1987. Glossary and Manual of Tetrapod Palaeoichnology. Departamento Nacional da Produção Mineral, Brasília, 117 pp.

Lockley, M.G., 1991. Tracking Dinosaurs: A New Look at an Ancient World. Cambridge University Press, Cambridge, 238 pp.

Lockley, M.G., Conrad, K., 1989. The paleoenvironmental context, preservation and paleoecological significance of dinosaur tracksites in the western USA. In: Gillette, D.D., Lockley, M.G. (Eds.), Dinosaur Tracks and Traces. Cambridge University Press, Cambridge, pp. 121-134.

Lockley, M.G., Santos, V.F., 1993. A preliminary report on sauropod trackways from the Avelino Site, Sesimbra Region, Upper Jurassic, Portugal. Gaia 6, 38-42.

Lockley, M.G., Meyer, C.A., Hunt, A.P., Lucas, S.G., 1994a. The distribution of sauropod tracks and trackmakers. Gaia 10, 233-248.

Lockley, M.G., Meyer, C.A., Santos, V.F., 1994b. Trackway evidence of a herd of juvenile sauropods from the Late Jurassic of Portugal. Gaia 10, 27-35.

Lockley, M.G., Meyer, C.A., Santos, V.F., 1998. Megalosauripus and the problematic concept of megalosaur footprints. Gaia 14, 313-337.

Lockley, M.G., Wright, J.L., Thies, D., 2004. Some observations on the dinosaur tracks at Münchehagen (Lower Cretaceous), Germany. Ichnos 11, 261-274.

Madeira, J., Dias, R., 1983. Novas pistas de dinosáurios no Cretácico Inferior. Comunicações dos Serviços Geológicos de Portugal 69, 147-158.

Manning, P.L., 2008. T. rex speed trap. In: Carpenter, K., Larson, P.L. (Eds.), Tyrannosaurus rex, the Tyrant King. Indiana University Press, Bloomington, pp. 204-231.

Marty, D., Strasser, A., Meyer, C.A., 2009. Formation and taphonomy of human footprints in microbial mats of present-day tidal-flat environments: implications for the study of fossil footprints. Ichnos 16, 127-142.
Mateus, O., Antunes, M.T., 2003. A new dinosaur tracksite in the Lower Cretaceous of Portugal. Ciências da Terra (UNL) 15, 253-262.

Mateus, O., Milàn, J., 2005. Ichnological evidence for giant ornithopod dinosaurs in the Late Jurassic Lourinhã Formation, Portugal. In: Le Loeuff, J., Galobart, A. Oms, O., Vila, B., Marmi, J. (Eds.), Abstract Book of the International Symposium on Dinosaurs and other Vertebrates Palaeoichnology. Fumanya - St. Corneli, Cercs, Barcelona, Spain, October 4-8, 2005, p. 64.

Mateus, O., Milàn, J., 2008. Ichnological evidence for giant ornithopod dinosaurs in the Upper Jurassic Lourinhã Formation, Portugal. Oryctos 8, 47-52.

McDonald, A.T., 2012. The status of Dollodon and other basal iguanodonts (Dinosauria: Ornithischia) from the Lower Cretaceous of Europe. Cretaceous Research $33,1-6$.

McDonald, A.T., Barrett, P.M., Chapman, S.D., 2010. A new basal iguanodont (Dinosauria: Ornithischia) from the Wealden (Lower Cretaceous) of England Zootaxa 2569, 1-43.

McKee, E.D., Ward, W.C., 1983. Eolian environment. In: Scholle, R.A., Bebout, D.G. Moore, C.H. (Eds.), Carbonate Depositional Environments. American Association of Petroleum Geologists Memoir 33, pp. 131-170.

Meyer, C.A., Thüring, B., 2003. The first iguanodontid dinosaur tracks from the Swiss Alps (Schrattenkalk Formation, Aptian). Ichnos 10, 221-228.

Meyer, C.A., Lockley, M.G., Robinson, J.W., Santos, V.F., 1994. A comparison of wellpreserved sauropod tracks from the Late Jurassic of Portugal and the western United States: evidence and implications. Gaia 10, 57-64.

Milàn, J., 2006. Variations in the morphology of emu (Dromaius novaehollandiae) tracks reflecting differences in walking pattern and substrate consistency: ichnotaxonomic implications. Palaeontology 49, 405-420.

Milàn, J., Bromley, R.G., 2006. True tracks, undertracks and eroded tracks, experimental work with tetrapod tracks in laboratory and field. Palaeogeography, Palaeoclimatology, Palaeoecology 231, 253-264.

Milàn, J., Clemmensen, L.B., Bonde, N., 2004. Vertical sections through dinosaur tracks (Late Triassic lake deposits, East Greenland) - undertracks and other subsurface deformation structures revealed. Lethaia 37, 285-296.

Moratalla, J.J., 1993. Restos indirectos de dinosaurios del registro español: paleoicnología de la Cuenca de Cameros (Jurásico superior-Cretácico inferior) y paleoología del Cretácico superior. Tesis Doctoral, Facultad de Ciencias, Universidad Autónoma de Madrid, 729 pp. (unpublished).

Moratalla, J.J., Hernán, J., 2008. Los Cayos S y D: dos afloramientos con icnitas de saurópodos, terópodos y ornitópodos en el Cretácico inferior del área de Los Cayos (Cornago, La Rioja, España). Estudios Geológicos 64, 161-173.

Moratalla, J.J., Sanz, J.L., Jiménez, S., 1988. Multivariate analysis on Lower Cretaceous dinosaur footprints: discrimination between ornithopods and theropods. Geobios 21, 395-408

Naish, D., Martill, D.M., 2008. Dinosaurs of Great Britain and the role of the Geological Society of London in their discovery: Ornithischia. Journal of the Geological Society, London 165, 613-623.

Nicosia, U., Petti, F.M., Perugini, G., D’Orazi Porchetti, S., Sacchi, E., Conti, M.A., Mariotti, N., Zarattini, A., 2007. Dinosaur tracks as paleogeographic constraints: new scenarios for the Cretaceous geography of the Periadriatic Region. Ichnos $14,69-90$.

Norman, D.B., 2002. On Asian ornithopods (Dinosauria: Ornithischia). 4. Probac trosaurus Rozhdestvensky, 1966. In: Norman, D.B., Gower, D.J. (Eds.), Archosaurian anatomy and palaeontology. Essais in memory of Alick D. Walker. Zoological Journal of the Linnean Society, 136, 113-144.

Norman, D.B., 2004. Basal Iguanodontia. In: Weishampel, D.B., Dodson, P., Osmólska, H. (Eds.), The Dinosauria, second ed. University of California Press, Berkeley, pp. 413-437.

Norman, D.B., 2010. A taxonomy of iguanodontians (Dinosauria: Ornithopoda) from the lower Wealden Group (Cretaceous: Valanginian) of southern England. Zootaxa 2489, 47-66.

Norman, D.B., Barrett, P.M., 2002. Ornithischian dinosaurs from the Lower Cretaceous (Berriasian) of England. In: Milner, A.R., Batten, D.J. (Eds.), Life and Environments in Purbeck Times. Special Papers in Palaeontology 68, pp. 161-189.

Ortega, F., Escaso, F., Gasulla, J.M., Dantas, P., Sanz, J.L., 2006. Dinosaurios de la Península Ibérica. Estudios Geológicos 62, 219-240.

Palain, C., 1975. Une série détritique terrigène. Les "Grés de Silves": Trias et Lias inférieur du Portugal. Thèse d'Etat, Université de Nancy, 503 pp. (unpublished)

Palain, C., 1976. Une série détritique terrigène. Les "Grés de Silves": Trias et Lias inférieur du Portugal. Memórias dos Serviços Geológicos de Portugal, Nova Série 25, 1-377.

Pascual-Arribas, C., Hernández-Medrano, N., Latorre-Macarrón, P., Sanz-Pérez, E. 2009. El icnogénero Iguanodontipus en el yacimiento de "Las Cuestas I" (Santa Cruz de Yanguas, Soria, España). Studia Geologica Salmanticensia 45, 105-128.

Paul, G.S., 2006. Turning the old into the new: a separate genus for the gracile iguanodont from the Wealden of England. In: Carpenter, K. (Ed.), Horns and Beaks: Ceratopsian and Ornithopod Dinosaurs. Indiana University Press, Bloomington, pp. 69-77.

Paul, G.S., 2008. A revised taxonomy of the iguanodont dinosaur genera and species. Cretaceous Research 29, 192-216.

Petti, F.M., D’Orazi Porchetti, S., Conti, M.A., Nicosia, U., Perugini, G., Sacchi, E., 2008. Theropod and sauropod footprints in the Early Cretaceous (Aptian) Apenninic Carbonate Platform (Esperia, Lazio, Central Italy): a further constraint on the palaeogeography of the central-Mediterranean area. Studi Trentini di Scienze Naturali, Acta Geologica 83, 323-334. 
Piñuela Suárez, L., 2000. Icnitas de dinosaurios bípedos del Jurásico de Asturias. Morfometría, morfología e interpretación. Diploma de Estudios Avanzados, Departamento de Geología, Universidad de Oviedo, 63 pp. (unpublished).

Rey, J., 1972. Recherches géologiques sur le Crétacé inférieur de l'Estremadura (Portugal). Memórias dos Serviços Geológicos de Portugal, Nova Série 21,1-477.

Rey, J., 1983. Le Crétacé de l'Algarve: essai de synthèse. Comunicações dos Serviços Geológicos de Portugal 69, 87-101.

Rey, J., 1986. Micropaleontological assemblages, paleoenvironments and sedimentary evolution of Cretaceous deposits in the Algarve (southern Portugal) Palaeogeography, Palaeoclimatology, Palaeoecology 55, 233-246.

Rey, J., 2006a. Les formations Crétacées de l'Algarve Occidental et Central. Comunicações Geológicas 93, 39-80.

Rey, J., 2006b. Stratigraphie séquentielle et séquences de dépôt dans le Crétacé Inférieur du Bassin Lusitanien. Ciências da Terra (UNL) 6 (Volume Especial), $1-120$.

Rey, J., 2009. Les formations Crétacées de l'Algarve Oriental. Comunicações Geológicas 96, 19-38.

Rey, J., 2010. La dynamique sédimentaire des Bassins Lusitanien et de l'Algarve au Crétacé Inférieur. Ciências da Terra (UNL) 17, 45-52.

Rey, J., Ramalho, M.M., 1973-1974. Le Crétacé Inférieur de l'Algarve Occidenta (Portugal). Comunicações dos Serviços Geológicos de Portugal 57, 155-182.

Rey, J., Dinis, J.L., Callapez, P., Cunha, P.P., 2006. Da rotura continental à margem passiva. Composição e evolução do Cretácico de Portugal. Cadernos de Geologia de Portugal, INETI, Lisboa, 75 pp.

Rocha, R.B., Ramalho, M.M., Antunes, M.T., Coelho, A.V.P., 1983. Carta Geológica de Portugal na Escala de 1:50000. Notícia Explicativa da Folha 52-A (Portimão) Serviços Geológicos de Portugal, Lisboa, 57 pp.

Rodrigues, N.P.C., Buscalioni, A.D., Santos, V.F., Fregenal-Martínez, M.A., 2008. Vertebrate microremains from the Lower Barremian at $\mathrm{N}$ of Cabo Espichel (Sesimbra, Portugal): historical review and preliminary results. In: Mazin, J.-M., Pouech, J., Hantzpergue, P., Lacombe, V. (Coords.), Mid-Mesozoic Life and Environments, Cognac, France, June 24-28, 2008. Documents des Laboratoires Géologie de Lyon 164, pp. 79-82.

Ruiz-Omeñaca, J.I., 2011. Delapparentia turolensis nov. gen et sp., un nuevo dinosaurio iguanodontoideo (Ornithischia: Ornithopoda) en el Cretácico Inferior de Galve. Estudios Geológicos 67, 83-110.

Ruiz-Omeñaca, J.I., Canudo, J.I., 2003. Dinosaurios (Saurischia, Ornithischia) en el Barremiense (Cretácico Inferior) de la Península Ibérica. In: Pérez-Lorente, F., Romero, M., Rivas Carrera, P. (Coords.), Dinosaurios y otros Reptiles Mesozoicos en España. Instituto de Estudios Riojanos, Universidad de La Rioja, Logroño, Spain, 26-29 de noviembre de 2002. Ciencias de la Tierra 26, pp. 269-312.

Ruiz-Omeñaca, J.I., Canudo, J.I., 2004. Dinosaurios ornitópodos del Cretácico inferior de la Península Ibérica. In: Liesa Carrera, C., Pocovi Juan, A., Sancho Marcén, C., Colombo Piñol, F., González Rodríguez, A., Soria de Miguel, A.R. (Eds.), VI Congreso Geológico de España, Zaragoza, Spain, 12-15 de julio de 2004. GeoTemas 6, pp. 63-65.

Ruiz-Omeñaca, J.I., Canudo, J.I., Aurell, M., Bádenas, B., Barco, J.L., Cuenca-Bescós, G. Ipas, J., 2004. Estado de las investigaciones sobre los vertebrados del Jurásico Superior y Cretácico Inferior de Galve (Teruel). Estudios Geológicos 60, 179-202.

Ruiz-Omeñaca, J.I., Canudo, J.I., Cuenca-Bescós, G., 1998. Sobre las especies de Iguanodon (Dinosauria, Ornithischia) encontradas en el Cretácico inferior de España. Geogaceta 24, 275-277.

Ruiz-Omeñaca, J.I., Pereda Suberbiola, X., Torcida Fernández-Baldor, F., Maisch, M. Izquierdo, L.A., Huerta, P., Contreras, R., Montero Huerta, D., Pérez Martínez, G., Urién Montero, V., Welle, J., 2009. Resto mandibular de ornitópodo iguanodontoideo (Dinosauria) del Cretácico Inferior de Salas de los Infantes (Burgos) en las colecciones del Institut für Geowissenschaften de Tubinga (Alemania). Geogaceta 45, 63-66.

Russell, D., Russell, D., 1977. Premiers résultats d'une prospection paléontologique dans le Trias de l'Algarve (Portugal). Ciências da Terra (UNL) 3, 167-178.

Sacchi, E., Conti, M.A., D’Orazi Porchetti, S., Logoluso, A., Nicosia, U., Perugini, G. Petti, F.M., 2009. Aptian dinosaur footprints from the Apulian platform
(Bisceglie, Southern Italy) in the framework of periadriatic ichnosites. Palaeogeography, Palaeoclimatology, Palaeoecology 271, 104-116.

Santos, V.F., 2003. Pistas de dinossáurio no Jurássico-Cretácico de Portugal. Considerações paleobiológicas e paleoecológicas. Tese de Doutoramento, Facultad de Ciencias, Universidad Autónoma de Madrid, 365 pp. (unpublished).

Santos, V.F., Dantas, P., Moratalla, J.J., Terrinha, P., Coke, C., Agostinho, M., Galopim de Carvalho, A.M., 2000a. Primeiros vestígios de dinossáurios na Orla Mesozóica Algarvia, Portugal. In: Diez, J.B., Balbino, A.C. (Eds.), Libro de Resúmenes del I Congreso Ibérico de Paleontología ( XVI Jornadas de la Sociedad Española de Paleontología, Évora, Portugal, 12-14 de Outubro de 2000, pp. 20-21.

Santos, V.F., Dantas, P., Moratalla, J.J., Terrinha, P., Coke, C., Agostinho, M., Galopim de Carvalho, A.M., 2000b. Rastos de Iguanodontídeos no Cretácico da Bacia Algarvia, Portugal. In: Diez, J.B., Balbino, A.C. (Eds.), Libro de Resúmenes del I Congreso Ibérico de Paleontología / XVI Jornadas de la Sociedad Española de Paleontología, Évora, Portugal, 12-14 de Outubro de 2000, pp. 22-23.

Santos, V.F., Lockley, M.G., Meyer, C.A., Carvalho, J., Galopim de Carvalho, A.M., Moratalla, J.J., 1994. A new sauropod tracksite from the Middle Jurassic of Portugal. Gaia 10, 5-13.

Santos, V.F., Lockley, M.G., Moratalla, J.J., Galopim de Carvalho, A.M., 1992. The longest dinosaur trackway in the world? Interpretations of Cretaceous footprints from Carenque, near Lisbon, Portugal. Gaia 5, 18-27.

Santos, V.F., Moratalla, J.J., Dantas, P.M., Coke, C., Cachão, M.A., Silva, C.M., Sousa, L.N., 1991. Icnofósseis de Dinossáurios do Cenomaniano médio da região de Lisboa. In: Actas do III Congresso Nacional de Geologia, Coimbra, Portugal, Outubro de 1991, p. 133.

Santos, V.F., Moratalla, J.J., Royo-Torres, R., 2009a. New sauropod trackways from the Middle Jurassic of Portugal. Acta Palaeontologica Polonica 54, 409-422.

Santos, V.F., Rodrigues, L.A., Rodrigues, N.P.C., Royo-Torres, R., 2009b. Middle Jurassic Theropod tracks from Portugal. In: Buscalioni, A., Fregenal-Martínez, M. (Eds.), Abstract Book of the Tenth International Symposium on Mesozoic Terrestrial Ecosystems and Biota, Teruel, Spain, September 17-19, 2009, pp. 151-152.

Sanz, J.L., Casanovas, M.L., Santafé, J.V., 1982. Paleontología. In: Geología y Paleontología (Dinosaurios) de las Capas Rojas de Morella (Castellón, España). Diputación Provincial de Castellón y Diputació de Barcelona, Castellón/Barcelona, Spain, pp. 69-169.

Sarjeant, W.A.S., Delair, J.B., Lockley, M.G., 1998. The footprints of Iguanodon: a history and taxonomic study. Ichnos 6, 183-202.

Sauvage, H.E., 1896. Les crocodiliens et les dinosauriens des terrains mésozoïques du Portugal. Bulletin de la Société Géologique de France 24, 46-48.

Sauvage, H.E., 1897-1898. Vertébrés fossiles du Portugal. Contribution à l'étude des poissons et des reptiles du Jurassique et du Crétacique. Mémoires de la Direction des Travaux Géologiques du Portugal, Lisbonne, 46 pp.

Sauvage, H.E., 1898. Les reptiles et les poissons des terrains mésozoïques du Portugal. Bulletin de la Société Géologique de France 26, 442-446.

Shinn, E.A., 1983. Tidal flat environments. In: Scholle, P.A., Bebout, D.G., Moore, C.H. (Eds.), Carbonate Depositional Environments. American Association of Petroleum Geologists Memoir 33, pp. 171-210.

Thulborn, R.A., 1990. Dinosaur Tracks. Chapman \& Hall, London, 410 pp.

Torcida Fernández-Baldor, F., Canudo, J.I., Huerta, P., Montero, D., Pereda Suberbiola, X., Salgado, L., 2011. Demandasaurus darwini, a new rebbachisaurid sauropod from the Early Cretaceous of the Iberian Peninsula. Acta Palaeontologica Polonica 56, 535-552.

Torcida Fernández-Baldor, F., Izquierdo Montero, L.A., Contreras Izquierdo, R., Huerta, P., Montero Huerta, D., Pérez Martínez, G., Urén Montero, V., 2006. Un dinosaurio "iguanodóntido" del Cretácico Inferior de Burgos (España). In: Torcida Fernández-Baldor, F., Huerta Hurtado, P. (Coords.), Actas de las III Jornadas Internacionales sobre Paleontología de Dinosaurios y su Entorno, Salas de los Infantes, Burgos, Spain, 16-18 de septiembre de 2004, pp. 349-363.

Wings, O., Broschinski, A., Knötschke, N., 2005. New theropod and ornithopod dinosaur trackways from the Berriasian of Münchehagen (Lower Saxony, Germany). Kaupia, Darmstädter Beiträge zur Naturgeschichte 14, 105.

Ziegler, P.A., 1988. Evolution of the Arctic-North Atlantic and the Western Tethys. American Association of Petroleum Geologists Memoir 43, 1-198. 